\title{
ACCESS TO EU FUNDS VS. FINANCIAL RISKS FACED BY RURAL MUNICIPALITIES OF THE WIELKOPOLSKIE VOIVODESHIP
}

\author{
Aldona Standar ${ }^{1}$,Ph.D. \\ ${ }^{1}$ Poznan University of Life Sciences
}

\begin{abstract}
The purpose of this study was to present the rural municipalities' access to EU funds and their impact on the occurrence of financial risks. One of the Poland's largest voivodeships, Wielkopolskie, was used as the example. A group of 116 rural local government units were assumed to be the subject matter of this study. The timeframes for this study are the period from 2006 to 2015. Because of the complex nature of the municipalities' financial operations, they were expressed with a selected group of indices divided into four groups in line with an approach adopted by the author. A variance analysis was performed to check whether the level of EU funds accessed had a statistically significant impact on the results regarding specific risk characteristics of the municipalities' financial operations. The author also used the descriptive and comparative methods as well as selected descriptive statistics methods and the Pearson correlation coefficient. In this study, the municipalities demonstrated different levels of access to EU funds. Generally, smaller, peripheral units proved to be more effective in accessing EU aid than larger ones located next to big urban centres. As shown by the variance analysis, the level of aid accessed has a statistically significant impact on the local government units' financial operations, in addition to financial liquidity. Note that higher absorption levels were correlated with smaller financial autonomy and greater indebtedness.
\end{abstract}

Key words: EU funds, financial risks, local government, variance analysis.

JEL code: H7O, H71, H72

\section{Introduction}

For more than ten years now, Polish local government have been eligible for aid measures from the European Union. The allocation structure, available levels and shares of financing have evolved in line with the frameworks of EU's subsequent financial perspectives. While supporting the very necessary infrastructural transformations in numerous municipalities, the funds also contributed to human capital improvement. Generally, they were supposed to stimulate development as provided for in the Treaty on European Union, primarily by driving growth of less developed areas.

The amount of funds accessed by municipalities is affected by many factors, mainly including the beneficiary's financial situation (Standar A. and Puslecki Z., 2011). When it comes to absorbing this kind of aid, the financial situation is all the more important since the beneficiaries must implement the investment by themselves first. Afterwards, they are provided with a partial refund (at a level ranging from $75 \%$ to $85 \%$ of expenses) while the remaining part is their own contribution. Therefore, this system of EU aid absorption may contribute to emergence of various threats to the municipality's financial operations, e.g. indebtedness (Poniatowicz M., 2005), restriction of financial autonomy (Kozera A. et al., 2016) or insolvency (Kosak-Wojnar M. and Wojnar J., 2005). The beneficiary is required to secure financial resources for the implementation of the entire investment. This is why less wealthy municipalities make broad use of repayable funds. In the future, this could result in restricting their income potential as they will be required to repay the debt with interest. Also, waiting for a refund of amounts disbursed in advance could adversely affect their liquidity. While that problem is addressed only to a limited extent in the literature, it is noteworthy because equally important investment funds are secured for the Polish local government units in the next financial perspective 2014-2020.

The purpose of this study was to present the rural municipalities' access to EU funds and their impact on the occurrence of financial risks. According to the research hypothesis advanced in this paper, the operations of municipalities involve financial risks caused by the absorption of EU funds. 
Therefore, studies need to be conducted on this issue to identify the scale and measurement methods of these developments. Thus, the following research tasks are set out: to present the level of EU funds available in Poland; to identify the scale and diversification of aid accessed by local government units under consideration; and to assess the impact of EU subsidies accessed on financial risk areas in local government operations. One of the Poland's largest voivodeships, Wielkopolskie, was used as the example. With an area of $29.826 .50 \mathrm{sq} . \mathrm{km}$ and a population of 3.47 million, Wielkopolskie is the country's second and third largest voivodeship, respectively. It comprises of 226 municipalities, including 4 urban districts, 19 urban municipalities, 91 urban-rural municipalities and 116 rural municipalities. A group of 116 rural local government units were assumed to be the subject matter of this study. This voivodeship represents the wealthiest local government units in Poland, rich in natural resources (e.g. lignite, gas). Good soils are conducive to agricultural development. In turn, highly developed infrastructure and their location near the Berlin-Warsaw transit road are the reasons for a dynamic growth of entrepreneurship (Central Statistical Office). The timeframes for this study are the period from 2006 to 2015. Because of the complex nature of the municipalities' financial operations, they were expressed with a selected group of indices. To do so, a desk review of the relevant literature was performed, and the recommendations of the Ministry of Finance (Indexes for the assessment...) were complied with. Also, a dedicated database (www.mf.gov.pl) was used. The source materials also originate from the Local Data Bank of the Central Statistical Office. On that basis, a group of indices were identified and were subsequently divided into four groups in line with an approach adopted by the author: risks involved in financial autonomy (share of own incomes in total incomes [\%], current transfers per capita [PLN]); risks related to the investment capacity and financial liquidity (share of the operating surplus in total incomes $[\%]$, share of the operating surplus and property incomes in property expenses [\%]); expenditure-related risks (share of remunerations and similar expenses in current expenditure [\%]); risks involved in liabilities (total liabilities per capita [PLN], share of total liabilities in total incomes [\%], share of debt-servicing costs in total incomes [\%]).

Indices reflecting the amount of EU funds accessed were assumed to be the level of subsidies absorbed per capita (cumulative amount in the 2006-2015 period) and the share of EU funds in total income (median from the period concerned). Based on the arithmetic mean $\overline{\mathrm{q}}$ and standard deviation ${ }^{\mathrm{s}_{\mathrm{q}}}$ of the two indices referred to above, the municipalities were divided into four classes: class 1 (high level) $\mathrm{q}_{\mathrm{i}} \geq \overline{\mathrm{q}}+\mathrm{s}_{\mathrm{q}}$, class 2 (medium-high level) $\overline{\mathrm{q}}+\mathrm{s}_{\mathrm{q}}>\mathrm{q}_{\mathrm{i}} \geq \overline{\mathrm{q}}$, class 3 (medium-low level) $\overline{\mathrm{q}}>\mathrm{q}_{\mathrm{i}} \geq \overline{\mathrm{q}}-\mathrm{s}_{\mathrm{q}}$, class 4 (low level): $\mathrm{q}_{\mathrm{i}}<\overline{\mathrm{q}}-\mathrm{s}_{\mathrm{q}}$.

A variance analysis was performed to check whether the level of EU funds accessed had a statistically significant impact on the results regarding specific risk characteristics of the municipalities' financial operations. The variance analysis used for that purpose specifies how likely it is for the identified factors to cause the differences between the group mean values observed (Stanisz A., 2016, p. 337, 386). Checking the normality of the distribution is a prerequisite for variance methods. To do so, the Shapiro-Wilk test (SW-W) was used. For the variables labelled "share of the operating surplus and property incomes in property expenses" (SW-W=0.93 for $p=0.00$ ) and "share of debt-servicing costs in total incomes," ( $W W-W=0.91$ for $p=0,00$ ) the Shapiro-Wilk test resulted in rejecting the null hypothesis of normality at $p=0.05$. Therefore, later in this study, the Kruskal-Wallis ANOVA (KW) nonparametric test and the $\mathrm{p}$ value were used for 
multiple comparisons. The distribution of other variables was normal within the groups (SW-W ranged from 0.96 to 0.99 for $p$ significance levels from 0.06 to 0.18 ), enabling the use of ANOVA variance analysis; the Fisher-Snedecor test was calculated $(F)$. The author also used the descriptive and comparative methods as well as selected descriptive statistics methods and the Pearson correlation coefficient. The data were arranged in tables and figures and were mapped.

\section{Research results and discussion}

Poland is the largest beneficiary of European funds (Fig. 1). Even though the European Union budget decreased in the 2014-2020 financial perspective compared to the 2007-2013 period from EUR 1.035 billion to EUR 997 billion, the guaranteed support for Poland increased from EUR 102 billion to EUR 106 billion (www.msz.gov.pl). The largest part of aid was allocated to measures under regional programs dedicated to 16 Polish voivodeships and infrastructure (www.funduszeeuropejskie.gov.pl). The main beneficiaries were local government units, including (in Poland) the municipalities as the basic territorial division units.

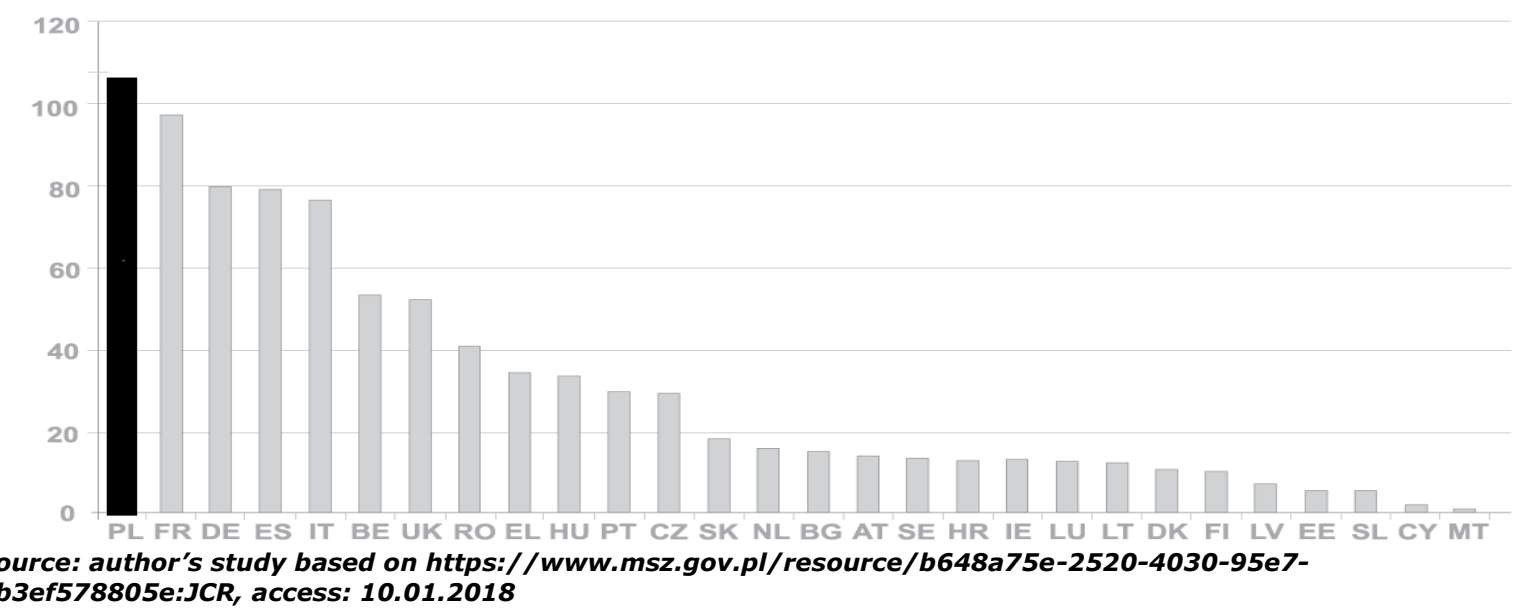

Fig. 1. Allocation of European Union funds between member countries (euro billion)

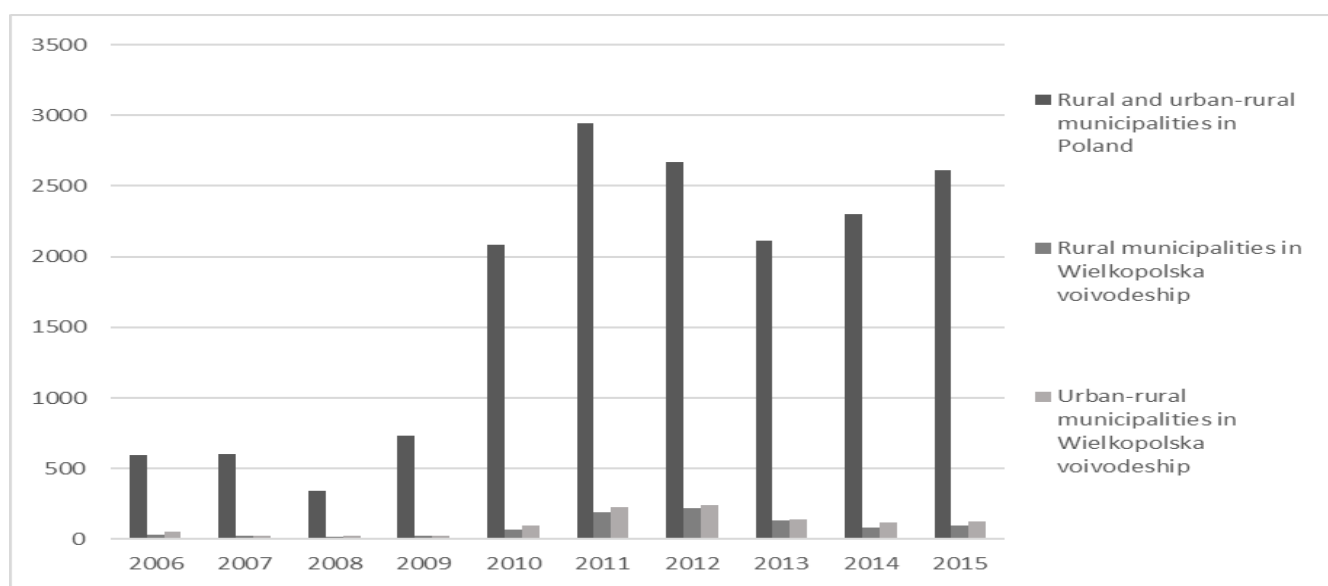

Source: author's study based on the Local Data Bank of the Central Statistical Office. Access: 09.01.2018

Fig. 2. Amounts of EU funds accessed by rural municipalities and urban-rural municipalities in Poland and in the Wielkopolskie voivodeship (PLN million)

In Poland, in the period under analysis, rural municipalities and urban-rural municipalities accessed a total pool of PLN 16.998 million. The amount of funds absorbed has become increasingly important since 2010 because of European Union aid implementation as a part of the 2007-2013 perspective. A similar trend may be observed when analysing the level of support accessed by selected groups of municipalities in the Wielkopolskie voivodeship: the urban-rural and 
urban municipalities accessed a total pool of PLN 1.951 million, which is $11.5 \%$ of total funds accessed by these types of municipalities in Poland. Approximately $55 \%$ and $45 \%$ of the funds were allocated to urban-rural municipalities and rural municipalities, respectively. When it comes to the amount of funds accessed per municipality, urban-rural units proved to be more effective beneficiaries than their rural counterparts, reaching the levels of PLN 9 million and PLN 7.5 million respectively, in the decade under consideration (Fig. 2).

Figure 3 shows the spatial differentiation of cumulated levels of EU funds accessed per capita and of the mean (median) share of EU funds accessed in the total incomes of rural municipalities of the Wielkopolskie voivodeship. Because of the similarities between the two maps, it was justified to verify the dependencies. As a consequence, a very strong relationship was discovered between these characteristics (a Pearson correlation coefficient of 0.96). This means that in the municipalities that absorbed important amounts of funds per capita the aid represented an equally significant part for the total budget (and vice versa). Therefore, later in this study, the indices reflecting the municipalities' financial risks were selected based on only one of the indices covered by this analysis: the amount of EU funds accessed per capita.
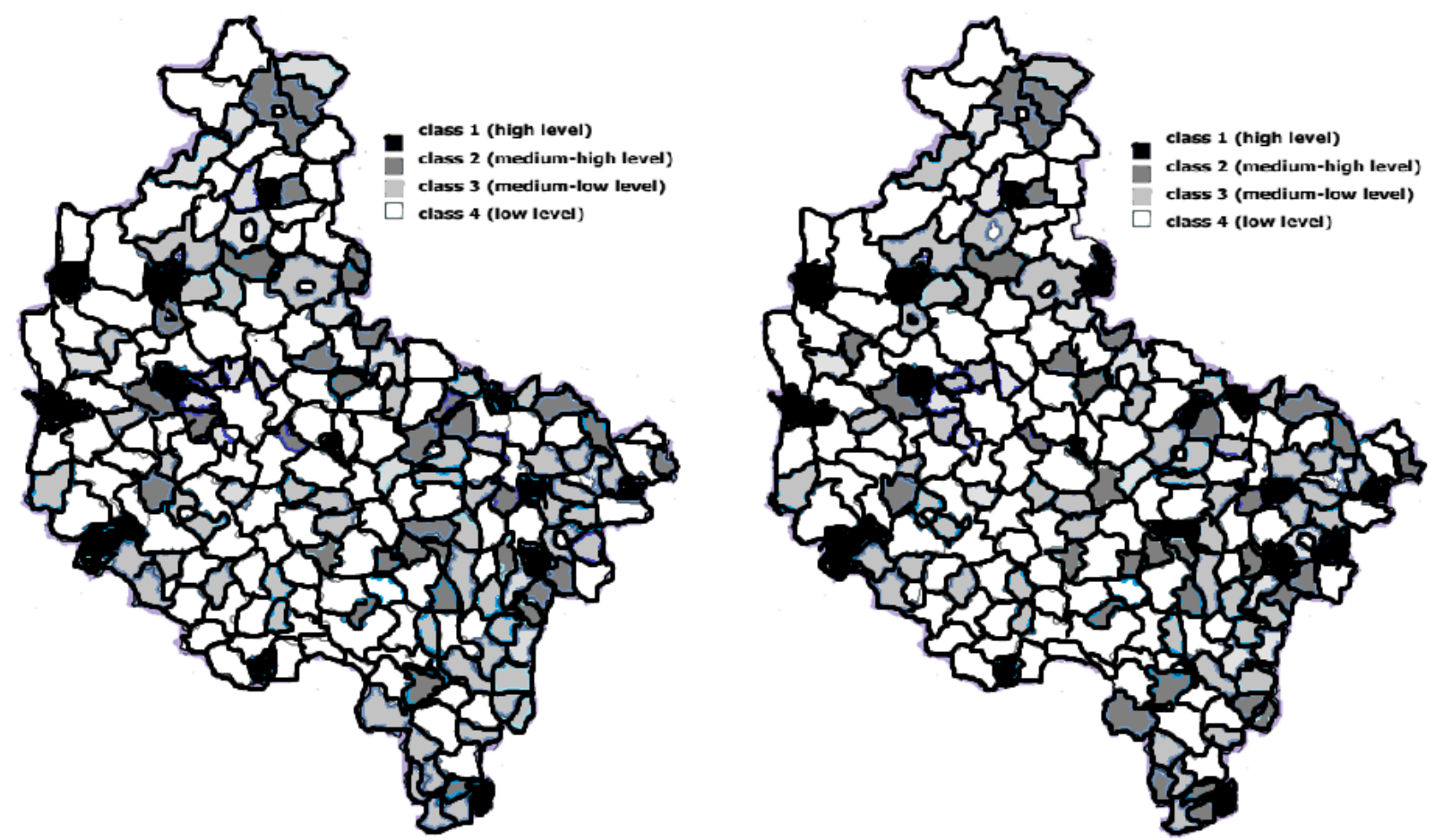

Source: author's study based on the Local Data Bank of the Central Statistical Office

Fig. 3. Delimitation of rural municipalities of the Wielkopolskie voivodeship by cumulated level of EU funds accessed per capita (left) and mean (median) share of EU funds accessed in the total incomes (right)

When analysing Figure 3 in more details, note that the amount of implemented EU aid varied across the municipalities. In smaller, peripheral municipalities (for large cities), such as Miasteczko Krajenskie, Malanow and Kazmierz, significant amounts of aid (even in excess of PLN 2.500 per capita) were accessed, whereas in larger ones (in terms of the number of inhabitants), located near big urban centres, e.g. Tarnowo Podgorne, Komorniki and Czerwonak, the aid accounted for barely several dozen PLN over the 10-year period. As regards the population of classes, the extreme classes No. 1 (high level) and 4 (low level) were less numerous, and represented 19 and 14 units, respectively. In most of municipalities, the amount of aid accessed 
fluctuated around the mean value, and thus groups 2 and 3 were composed of several dozen local government units.

Risk type identification by the Local Government Units (JST) is not an easy task, which is caused by the diversity of conducted activity and the points of view (the authorities, the citizen, the investor) (Dylewski M., Filipiak B and Gorzalczynska-Koczkodaj M., 2010). Financial risk results from the way of covering the cost of the Local Government Units tasks. It is connected with the flow of capital accumulated and spent from the Local Government Units' budget in the form of income and revenue and outgoings and expenses (Korenik D. and Korenik S., 2007). The fact that it is characterized by complexity is evident in the above mentioned research areas. Another aspect of risk in the Local Government Units focuses on the levels of risk. Kosak-Wojnar M. and Wojnar J. (2005) distinguish its three types: the risk of losing current liquidity, the risk of losing reliability and the risk of the Local Government Units insolvency. Generally, the risk analysis in the functioning of local government is an issue more extensively explored in international literature (e.g. Patrick P.A. and Trussel J.M., 2012; Kloha P. et al., 2005; Jones S. and Walker R., 2007; Hendrick R., 2004; Rivenbark W.C. and Roenigk D.J., 2011) than by Polish authors (Kata R., 2012; Standar A., 2017). The authors usually focus on a theoretical approach and on selecting the indicators. In his pioneering article, Kata (2012) stated that using only one indicator is inadequate considering some municipal characteristics. Note that these risks were not previously addressed in the context of the absorption of EU funds. Table 1 shows the results of variance analysis for the indices specific to the financial risks of rural municipalities in the Wielkopolskie voivodeship, ordered by amount of EU funds accessed per capita. A group of indices were identified and were subsequently divided into four groups in line with an approach adopted by the author. Afterwards, the analysis of variance was employed to measure the developments under consideration. That method was not used previously in this type of research. In the group of indices covered by this analysis, only two demonstrated statistically insignificant differences. This means the amounts of EU aid disbursed have a statistically significant impact on the municipalities' financial operations expressed with the use of other characteristics.

The first group of risks refers to financial autonomy. These risks are reflected by the share of own incomes in total incomes and by current transfers per capita. In Poland, own incomes are related to the municipality's own activity and are mainly represented by local taxes and fees, shares in personal and corporate income taxes, and other capital and property incomes (Act on the incomes...). A directly proportional relationship exists between the amount of own incomes and financial autonomy (Wisniewski M., 2011, p. 126). The important role of own income as a determinant of financial situation is also demonstrated in studies by A.Kozera et al. (2010). As found in the group covered by this analysis, the higher is the amount of EU funds accessed, the smaller is the beneficiaries' independence. This means the implementation of EU aid in Poland effectively supports less wealthy local government units. Otherwise, wealthier local government units (those with greater own incomes) would prove to be more efficient in accessing the funds because, unlike their less wealthy peers, they would not have any problems in securing funds for investments and delivering their own contribution. The above conclusion is corroborated by the results of variance analysis for the next characteristic: current transfers per capita. It turns out that the increase in the levels of EU aid accessed was accompanied by an increase in the support from state budget disbursed as subsidies and grants. Note, however, that the above system, which supports weaker units, may pose a risk to their functioning because if state support is limited, their 
capacity to implement projects co-financed by the EU will also be limited. This system makes the local government's functioning dependent upon state support.

Results of variance analysis for the indices specific to the financial risks of rural municipalities of the Wielkopolskie voivodeship, ordered by amount of EU funds accessed per capita

\begin{tabular}{|c|c|c|c|c|c|c|c|}
\hline Index & Class 1 & Class 2 & Class 3 & Class 4 & Total & $\mathbf{F} / \mathbf{K W} *$ & $\mathbf{p}$ \\
\hline \multicolumn{8}{|c|}{ Financial autonomy risks } \\
\hline $\begin{array}{l}\text { Share of own incomes in total } \\
\text { incomes }(\%)\end{array}$ & 36.47 & 38.66 & 40.12 & 49.35 & 40.50 & 3.08 & 0.0302 \\
\hline $\begin{array}{l}\text { Current transfers per capita } \\
\text { (PLN) }\end{array}$ & 1.868 .20 & 1.799 .42 & 1.725 .78 & 1.516 .81 & 1.737 .00 & 2.79 & 0.0439 \\
\hline \multicolumn{8}{|c|}{ Risks related to the investment capacity and financial liquidity } \\
\hline $\begin{array}{l}\text { Share of operating surplus in } \\
\text { total incomes }(\%)\end{array}$ & 8.76 & 10.43 & 9.50 & 11.70 & 10.00 & 1.37 & 0.2547 \\
\hline $\begin{array}{l}\text { Share of operating surplus } \\
\text { and property incomes in } \\
\text { property expenditure }(\%)\end{array}$ & 118.49 & 120.03 & 124.18 & 127.14 & 122.62 & $0.69 *$ & 0.8765 \\
\hline \multicolumn{8}{|c|}{ Expenditure-related risk } \\
\hline $\begin{array}{l}\text { Share of remunerations and } \\
\text { similar expenses in current } \\
\text { expenditure }(\%)\end{array}$ & 49.55 & 48.20 & 49.20 & 45.63 & 48.44 & 3.67 & 0.0144 \\
\hline \multicolumn{8}{|c|}{ Risks involved in liabilities } \\
\hline $\begin{array}{l}\text { Total liabilities per capita } \\
\text { (PLN) }\end{array}$ & 1.173 .50 & 880.16 & 680.83 & 1.046 .61 & 852.60 & 4.29 & 0.0067 \\
\hline $\begin{array}{l}\text { Share of total liabilities in } \\
\text { total incomes }(\%)\end{array}$ & 35.06 & 26.69 & 21.63 & 28.62 & 25.79 & 4.02 & 0.0093 \\
\hline $\begin{array}{l}\text { Share of debt-servicing costs } \\
\text { in total incomes }(\%)\end{array}$ & 9.44 & 8.66 & 6.01 & 6.91 & 7.37 & $9.90 *$ & 0.0194 \\
\hline
\end{tabular}

Note: F means the Fisher-Snedecor $(F)$ test; $K W$ means the Kruskal-Wallis test; $p$ means the significance level.

Source: author's calculations based on the Ministry of Finance Database and the Local Data Bank of the Central Statistical Office. Access: 09.01.2018

According to M. Dylewski (2014, p. 133-134), relatively low capacity to generate an operating surplus may be a financial risk factor causing excessive indebtedness not only in rural communes but also in other entities of the local government sector. Interestingly, the amount of EU aid accessed does not affect the risk of insolvency. This may be regarded as a surprising result, having in mind that the EU aid implementation system is based on the refunding principle. It requires the beneficiary to freeze the funds during the investment and to wait for a refund only upon partially or entirely completing the project. The Ministry of Finance considers the ratio of operating surplus (the difference between current incomes and current expenditure) to total incomes as an indicator of investment capacities and creditworthiness of a local government unit. A negative result suggests the emergence of threats to the municipalities' financial management (Indexes for the assessment..., 2014, p. 6). Additionally, from January 1, 2014, the level of operating surplus is important for specifying the limits of use of repayable sources (Article 243 of the Public Finance Act of 2009). For all municipality classes, positive results mean positive financial standing. The share of operating surplus index and property incomes in property expenditure is also at a satisfactory level. Referred to as the self-financing index by the Ministry, it specifies the financial liquidity level.

Another risk area for the municipalities is related to expenditure and is represented by a single feature: share of remunerations and similar expenses in current expenditure. If municipalities which access larger amounts of EU aid allocate statistically significantly more funds to remunerations and similar expenses, this reflects an unfavourable structure of funds disbursed. 
According to M. Dylewski, B. Filipiak and M. Gorzalczynska-Koczkodaj (2010, p. 88) in the future, this may create an imbalance in the allocation of funds between property and human resources, which could contribute to the risk of restricting the investment capacity.

The last area covered by this analysis is the over-indebtedness risk. The very important role of the over-indebtedness as a determinant of financial risks of municipalities is demonstrated in studies by A. Standar (2017). The amount of EU funds accessed turns out to be a statistically significant differentiator of the indebtedness level and of debt-servicing costs. Municipalities which accessed larger amounts of European Union aid made a statistically greater use of repayable funds when it comes to both per capita ratio and their share in total incomes. A greater debt means the need to secure funds not only for the future repayment but also for debt-servicing purposes. Overindebtedness may result in the need to borrow more funds (debt rollover); as a consequence, the borrowing municipality may fall into a debt trap. Also, in the future, the growing debt and debtservicing costs may result in the loss of investment capacity and financial liquidity because of the need to allocate increasingly more funds to repay the capital borrowed. Interesting conclusions also result from research by R. Kata (2012, p. 142-143), who proved that indebtedness and own income are the most important determinants of financial risk.

\section{Conclusions, proposals, recommendations}

1) Because Poland is an EU member, local government units may access significant subsidies, especially in the area of investments. In Poland, in the period under analysis, rural municipalities and urban-rural municipalities accessed a total pool of PLN 16,998 million. The amount of funds absorbed has become increasingly important since 2010 because of European Union aid implementation as part of the 2007-2013 perspective. A similar trend may be observed when analysing the level of support accessed by selected groups of municipalities in the Wielkopolskie voivodeship. In this study, the municipalities demonstrated different levels of access to EU funds. However, most of them reported a medium absorption level of EU aid. Generally, smaller, peripheral units proved to be more effective in accessing EU aid than larger ones located next to big urban centres. This means the principle of promoting less wealthy units is effectively implemented in Poland.

2) Local government units may use the EU funds to implement their investments despite a lower investment potential. However, they may face a problem related to the emergence of various financial risks in local government operations because the absorption of Union subsidies is a refund-based system. This paper attempts to estimate the impact of EU funds on financial risks grouped by the author. The analysis of variance proved to be useful for this type of studies, and was therefore employed for that purpose. As shown by the analysis, the level of aid accessed has a statistically significant impact on the local government units' financial operations, in addition to financial liquidity. Therefore, the hypothesis advanced in this paper is accepted. Note that higher absorption levels were correlated with smaller financial autonomy and greater indebtedness. In the future, both of these aspects may pose the risk of reducing the investment capacity which, in turn, may result in the risk of marginalization. Breaking this impasse may be even more difficult for less wealthier municipalities.

3) The results of this study only extend to rural municipalities of the Wielkopolskie voivodeship. Thus, they could be the starting point for further research on this topic, which 
becomes particularly important as the Polish local government units may access considerable support from the EU under the 2014-2010 financial perspective.

\section{Acknowledgement}

The project was financed from resources of the National Center for Science, allocated pursuant to decision DEC-2013/11/D/HS4/03884.

\section{Bibliography}

1. Act on the Incomes of Local Government Units of November 13, 2003 (Journal of Laws [Dz.U.] No. 203, item 1966).

2. Bank Danych Lokalnych Glownego Urzedu Statystycznego. (Local Data Bank of Central Statistical Office). Retrieved: http://www.bdl.gus.pl. Access: 09.01.2018.

3. Dylewski, M. (2014). Zadłużenie JST - problemy nowej perspektywy finansowej UE (Local Government Debt - Problems of a New Financial Perspective of the EU), Zeszyty Naukowe Uniwersytetu Ekonomicznego $w$ Katowicach, Studia Ekonomiczne, No. 198/14, p. 125-134.

4. Dylewski, M., Filipiak, B., Gorzalczynska-Koczkodaj, M. (2010). Metody analityczne w dzialalnosci jednostek podsektora samorzadowego (Analytical Methods in the Activity of Local Government Sub-sector Units), Difin, Warszawa.

5. Hendrick, R. (2004). Assessing and Measuring the Fiscal Health of Local Government: Focus on Chicago Suburban Municipalities. Urban Affairs Review, 40, pp. 78-114.

6. Jones, S., Walker, R. (2007). Explanators of Local Government Distress. Abacus, 43, pp. 396-418

7. Kata R. (2012): Ryzyko finansowe $w$ dzialalnosci jednostek samorzadu terytorialnego-metody oceny (Financial Risk in the Activities of Local Government Units - assessment methods), Zeszyty Naukowe SGGW EiOGŻ nr 97/2012, Wydawnictwo SGGW, Warszawa, p. 129-142.

8. Kloha, P., Weissert, C., Kleine, R. (2005) Developing and Testing a New Composite Model to Predict Local Fiscal Distress. Public Administration Review, 65, 3, pp. 313-323

9. Korenik, D., Korenik, S. (2007). Stosunki samorzadowo-bankowe a rozwoj spoleczno-ekonomiczny w przestrzeni (Relationships Between Local Government and Banks vs. Socio-economic Development), CeDeWu.PI

10. Kosak-Wojnar, M., Wojnar, J. (2005). Ryzyko utraty plynnosci jednostek samorzadu terytorialnego - proba kwantyfikacji (Insolvency Risk Faced by Local Government Units: a Quantification Attempt), Bochnia University of Economy, Scientific journal No. 3, pp. 37-53.

11. Kozera, A., Glowicka-Woloszyn, R., Wysocki, F. (2016). Samodzielnosc finansowa gmin wiejskich w woj. Wielkopolskim (Financial Autonomy of Rural Municipalities in the Wielkopolskie Voivodeship), Wiadomosci Statystyczne 2/2016, pp. 73-87.

12. Ministerstwo Finansow. (Ministry of Finance). Retrieved: http://www.mf.gov.pl. Access: 09.01.2018.

13. Ministerstwo Inwestycji i Rozwoju. (Ministry of Investment and Development). Retrieved: http://www.funduszeeuropejskie.gov.pl. Access: 15.01.2018.

14. Ministerstwo Spraw Zagranicznych. (Ministry of Foreign Affairs). Retrieved: https://www.msz.gov.pl. Access: 10.01.2018.

15. Patrick, P.A., Trussel, J.M. (2012) Predicting County Spending Priorities by Policy Area. Paper presented at the Annual Meeting of the American Accounting Association, Washington, DC

16. Poniatowicz, M. (2005). Dlug publiczny w systemie finansowym jednostek samorzadu terytorialnego (Public Debt in the Financial System of Local Government Units), Publishing House of Bialystok University, Bialystok.

17. Public Finance Act of 2009 (Journal of Laws [Dz.U.] of 2009, No. 157, item 1240).

18. Rivenbark, W. C., Roenigk, D. J. (2011) Implementation of Financial Condition Analysis in Local Government. Public Administration Quarterly, 35,pp. 241-267.

19. Standar, A. (2017). Zagrozenia w gospodarce finansowej samorzadow gminnych a wyrownywanie poziomu rozwoju lokalnego (Threats to the Financial Management of Municipal Government Units vs. Evening out Local Differences in Levels of Development), Nierownosci spoleczne a wzrost gospodarczy, Vol. 49, pp. 359371, DOI: 10.15584/nsawg.2017.1.27.

20. Standar, A., Puslecki, Z. (2011). Ocena zastosowania srodkow polityki regionalnej Unii Europejskiej przez samorzady gminne wojewodztwa wielkopolskiego (Assessing the Use of Funds under the European Union Regional Policy by Municipal Government Units in the Wielkopolskie Voivodeship), Publishing House of the Poznan University of Life Sciences, Poznan.

21. Stanisz, A. (2006). Przystepny kurs statystyki z zastosowaniem STATISTICA.PL na przykladzie z medycyny (An Accessible Statistics Course Based on STATISTICA.PL Illustrated by Medical Examples), vol. III, StatSoft Polska Publishing House, Krakow.

22. Wisniewski, M. (2011). Ocena zdolnosci kredytowej gminy (Assessing the Creditworthiness of a Municipality), Difin, Warsaw. 
Proceedings of the 2018 International Conference "ECONOMIC SCIENCE FOR RURAL DEVELOPMENT" No 49

Jelgava, LLU ESAF, 911 May 2018, pp. 169-177 DOI 10.22616/ESRD.2018.133

23. Wskazniki do oceny sytuacji finansowej jednostki samorzadu terytorialnego $w$ latach 2012-2014 (Indexes for the Assessment of the Financial Standing of Local Government Units in 2012-2014), Ministry of Finance, Warsaw, 2011, http://www.mf.gov.pl, (as on January 9, 2018). 